Ryszard KOWALSKI

Renata STOCZKOWSKA

Maria OBRĘBSKA

Urszula MARCISZEWSKA

WM Olecka

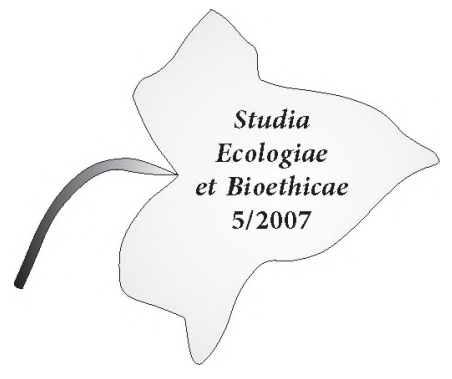

\title{
Edukacyjna funkcja gospodarstw agroturystycznych na przykładzie regionu siedleckiego
}

\section{Wstęp i przegląd piśmiennictwa}

Podstawową determinantą rozwoju turystyki wiejskiej, zwanej inaczej agroturystyką, jest atrakcyjność terenu. Osoby decydujące się na spędzenie urlopu w bezpośrednim kontakcie z przyrodą kierują się przy dokonywaniu wyboru miejsca pobytu, poza warunkami bytowymi, przede wszystkim pięknem krajobrazu i czystością wszystkich jego elementów: wody, powietrza, lasów. Wybierają się na wieś z zamiarem odpoczynku, ale często także planują, że uda im się poznać przy okazji nowe gatunki roślin i zwierząt, a także zaobserwować ciekawe zjawiska, o co nie jest trudno obcując z przyrodą. Dobrze jest, jeśli w wiejskim hoteliku, oprócz wygodnego pokoju i dobrej kuchni, goście zastaną gospodarzy przygotowanych do pełnienia roli przewodników, znających dobrze swój region i potrafiących interesująco opowiedzieć o znajdujących się na jego terenie osobliwościach. W ten sposób może i powinna realizować się ważna funkcja edukacji poprzez agroturystykę. Tę szansę nieformalnego kształcenia powinno się wykorzystać ze względu na postępującą degradację środowiska, do czego przyczynia się także turystyka.

Strategia rozwoju turystyki w Polsce na lata 2007-2013 promuje prośrodowiskowe formy turystyki, jak eko i agroturystyka oraz akcentuje potrzebę podnoszenia świadomości ekologicznej, zarówno turystów, jak i osób oferujących usługi w tej branży ${ }^{1}$.

Strategia rozwoju turystyki w Polsce na lata 2007-2013. 
W piśmiennictwie naukowym zdecydowanie przeważają publikacje poruszające ekonomiczne i prawne aspekty agroturystyki². Jest też dostępna pewna grupa artykułów, w których autorzy skupiają się na kulturowych, przyrodniczych i zdrowotnych problemach wypoczynku na wiejskiej kwaterze oraz wskazują na różnorodność zajęć na świeżym powietrzu, mających terapeutyczne działanie ${ }^{3}$.

Trzeba też wyróżnić trzecią grupę opracowań, w bezpośredni sposób związaną $z$ tematem poruszanym $w$ tym artykule, a mianowicie z edukacją przyrodniczą prowadzoną poprzez agroturystykę $e^{4}$ W literaturze ten rodzaj czynnego wy-

2 WILKIN J., 2003: Podstawy strategii zintegrowanego rozwoju rolnictwa i obszarów wiejskich $w$ Polsce, Uniwersytet Warszawski, Wydział Nauk Ekonomicznych, Warszawa; DęBNiewska M., 2000: Wptyw działalności pozarolniczej (w tym agroturystyki) na ekonomikę gospodarstwa rolnego. [w:] Rozwój agroturystyki i jej wplyw na przeobrazenia w rolnictwie i na wsi. Wydawnictwo Uniwersytetu Warmińsko - Mazurskiego, Olsztyn; Dryjańska E., 2002: Agroturystyka zbliża ludzi, daje zadowolenie i sukcesy, Poradnik Gospodarski nr 5; KrzyżanowsKa K., 1997: Uwarunkowania rozwoju agroturystyki jako formy wielofunkcyjnego zagospodarowania obszarów wiejskich [w:] Doradztwo w rozwoju agroturystyki. Wiatrak A. P.(red.) Konferencja naukowa, Warszawa; ŁЕ̨CZYCKI K., 2003: Wybrane zasoby i produkty w gospodarstwie agroturystycznym. Wydawnictwo Akademii Podlaskiej, Siedlce; Marks M., Marks E., Meynarczy K K., 2002: Znaczenie agroturystyki w rozwoju obszarów wiejskich, [w:], Agroturystyka, Mlynarczyk K. (red.), Wydawnictwo Uniwersytetu Warmińsko-Mazurskiego, Olsztyn; MıYNarczYK K., 2002: Uwarunkowania rozwoju agroturystyki w Polsce.[w:] Agroturystyka. Wydawnictwo Uniwersytetu Warmińsko-Mazurskiego, Olsztyn; Nowicka A., 2002: Alternatywne źródła dochodów, Poradnik Gospodarski nr 5; PAŁKA E., 2004: Uwarunkowania i kierunki rozwoju agroturystyki na Kielecczyźnie. Akademia Świętokrzyska, Kielce; Passaris S., Sokólska J., Vinaver K., 2002: Rozwój obszarów wiejskich i turystyka. Białystok, Paryż; SUdnIK M., JANKowSKI K., 2003: Rozwój agroturystyki na ziemi siedleckiej. [w:] Turystyka wiejska i agroturystyka stan i perspektywy rozwoju. Mirończuk A. (red.) Wydawnictwo Akademii Podlaskiej, Siedlce; ŻмIJA J., 1999: Przedsiębiorczość w agrobiznesie a rozwój obszarów wiejskich w Regionie Małopolski. Akademia Rolnicza Kraków; ŻMIJA J., 2002: Agroturystyka jako forma przedsiębiorczości na obszarach wiejskich zamojszczyzny; pod red. Antoniego Kożucha, Rozwój obszarów wiejskich teoria i praktyka, AP, Siedlce.

3 GoŁembnik M.,2003: Kronika Mazowiecka nr 7-8; Gozdalik U., Gozdalik A., 2003: Kulturowe, przyrodnicze i gospodarcze uwarunkowania rozwoju agroturystyki na lubelszczyźnie.[w:] Turystyka wiejska i agroturystyka stan i perspektywy rozwoju, Mirończuk A.(red.), Wydawnictwo Akademii Podlaskiej, Siedlce; Graja S., 2003: Dawne rzemiosto atrakcja turystyczna Polskiej wsi, [w:] Wybrane zasoby i produkty w gospodarstwie agroturystycznym, Łęczycki K., (red.), Wydawnictwo Akademii Podlaskiej, Siedlce; LoreK M., 2002: Rekreacja ze zwierzętami, [w:] Agroturystyka, Młynarczyk K. (red.), Wydawnictwo Uniwersytetu WarmińskoMazurskiego, Olsztyn; Kasperczyk M., Stawiński W., ŚWięTaszczyK-Kasperczyk W., DzIĄBEK W., 2007: Realizowanie założeń ekorozwoju w zakresie turystyki w powiecie i gminie Zawiercie. Wydawnictwo Kubajak. Kraków.

4 Piotrowski J., 2000: Dziedzictwo kulturowe - kapitał wsi. Fundacja Wspomagania Wsi. Warszawa; Roszkowska B., ZALEsko M., 1999: Możliwości rozwoju agroturystyki na obszarach chronionych, Materiały VII Ogólnopolskiego Sympozjum Agroturystycznego, Supraśl; Sikora J., 1999: Organizacja ruchu turystycznego na wsi, Wydawnictwo Szkolne i Pedagogiczne, Warszawa; STAWIŃski W., 2006: Turystyka wobec problemów przyrody i środowiska. Wydawnictwo „Kubajak”; Sudnik M., 2002: Agroturystyka na terenach nadburzańskich. Wieś Mazowiecka nr 4; 
poczynku połączonego z odkrywaniem tajemnic przyrody i uroków życia na wsi jest zaliczany do turystyki kwalifikowanej lub ekoturystyki ${ }^{5}$. Mówi się o nim, że jest to rodzaj podróżowania przyjazny środowisku, który odbywa się najczęściej na obszarach atrakcyjnych pod względem wartości przyrodniczych.

Ekoedukacyjną rolę gospodarstw agroturystycznych można rozpatrywać jako oferowanie turystom atrakcji, działań, zajęć czy stylu życia przyjaznych środowisku. Może ją wzmocnić postawa i wrażliwość właścicieli gospodarstwa na sprawy ochrony przyrody i środowiska. Gospodarz, obdarzony wysoką kulturą ekologiczną swoim przykładem, głównie w sposób niewerbalny, może oddziaływać jako nauczyciel sozologii. Może to robić poprzez prowadzenie upraw ekologicznych, wyrażając zgodę na utworzenie na jego prywatnych gruntach pomnika przyrody lub użytku ekologicznego, stosowanie urządzeń oszczędzających wodę, energię elektryczną, stosowanie selektywnej zbiórki odpadów, utrzymywanie porządku w obejściu gospodarskim, oczyszczanie ścieków w przyzagrodowej oczyszczalni, produkcję we własnym gospodarstwie artykułów spożywczych o wysokiej jakości, jak chleb, sery, masło itp.

Wybierając gospodarstwo agroturystyczne jako miejsce spędzenia wolnego czasu, szczególnie na obszarach cennych pod względem przyrodniczym i kulturowym, turysta powinien mieć świadomość, że decyduje się na pewien rygor związany z poszanowaniem przyrody i zabytków kultury tego obszaru. Docenienie wartości przyrodniczo kulturowych oznacza nie tylko aktualny zachwyt nimi, ale i refleksję na temat ich trwałości. W doświadczeniu tej refleksji i przeżyciu emocjonalnych, formujących poglądy i postawy spotkań z przyrodą i historią, mogą pomóc dobrze przygotowani właściciele gospodarstw agroturystycznych, jeśli potrafią przyjąć na siebie dodatkowo rolę przewodnika - nauczyciela.

\section{Metodyka i wyniki badań}

Celem badań było poznanie oferty edukacyjnej gospodarstw agroturystycznych w regionie siedleckim oraz znalezienie odpowiedzi na pytanie, czy gospodarze prowadzący usługi turystyczne są przygotowani do pełnienia funkcji przewodników po swoim regionie. Przystępując do planowania badań przeanalizowano materiały dostępne w Mazowieckim Ośrodku Doradztwa Rolniczego, w tym wydawnictwo pt.: „Mazowsze - agroturystyka 2005/2006”. Techniką wywiadu bezpośredniego przeprowadzono badania sondażowe $\mathrm{z}$ udziałem właścicieli 23

Turos L., 1997: Wprowadzenie do wiedzy o turystyce edukacyjnej, Stowarzyszenie Oświatowców Polskich, Warszawa. WoźNIAK M., 2002: Wplyw agroturystyki na architekturę krajobrazu obszarów wiejskich. Fragmenta Agronomica nr 19.

5 ZaRęBA D., 2000: Ekoturystyka wyzwania i nadzieje. Warszawa, Wydawnictwo Naukowe PWN. 
wytypowanych gospodarstw, spośród 54 zarejestrowanych wówczas na terenie powiatów: łosickiego, mińskiego, siedleckiego i węgrowskiego. Badania przeprowadzono w latach 2005-2006.

Region ten znajduje się poza wpływem wielkiego przemysłu. Są tutaj kompleksy leśne o dużym stopniu naturalności oraz wiele zabytków kultury, dlatego kwalifikuje się on do rozwoju agroturystycznej branży i przy okazji do prowadzenia nieformalnych działań edukacyjnych w zakresie ekologii, sozologii, historii, etnografii i w innych dziedzinach.

Rozmówcom, po wyrażeniu przez nich zgody, zadano pytania dotyczące działalności agroturystycznej w aspekcie społecznym, środowiskowym i edukacyjnym.

\section{Wyniki badań}

Głównym celem omawianych badań sondażowych było określenie, w jaki sposób działalność agroturystyczna łączy się z edukacją ludzi wybierających tę formę spędzania wolnego czasu. Pierwsze pytanie postawione rozmówcom dotyczyło tradycji prowadzenia działalności agroturystycznej w regionie. Odpowiedzi prowadzą do wniosku, ze na tym terenie usługi te zaczynają się dopiero rozwijać. Przeważają gospodarstwa mające staż nie dłuższy niż 7 lat w prowadzeniu obsługi ruchu turystycznego. Właściciele są na etapie zdobywania doświadczenia w prowadzeniu agrobiznesu i mogą mieć niewielkie rozeznanie w potrzebach gości i środowiskowej pedagogice.

Analiza ofert 54 gospodarstw agroturystycznych istniejących w regionie siedleckim, zamieszczonych w materiałach opracowanych przez Mazowiecki Ośrodek Doradztwa Rolniczego w roku 2005/2006 wykazała, że propozycje przygotowane dla turystów są różnorodne, ale dotyczą głównie usług socjalno-bytowych, a mniej edukacyjnych. Informację o rodzajach usług dodatkowych wiążących się z edukacją turystów, sporządzoną na podstawie informacji z MODR*, podano w tabeli 1 (Tab.1).

Tab.1 Oferta edukacyjna gospodarstw agroturystycznych regionu siedleckiego w kontekście edukacji przyrodniczo - kulturowej (na podstawie opracowania sporządzonego przez MODR)

\begin{tabular}{|c|c|c|c|c|c|}
\hline $\begin{array}{c}\text { Punkt oferty } \\
\text { (piktogramy) }\end{array}$ & $\begin{array}{c}\text { Poznawanie } \\
\text { historii i za- } \\
\text { bytków }\end{array}$ & $\begin{array}{c}\text { Poznawanie } \\
\text { folkloru, rze- } \\
\text { miosła, sztuki } \\
\text { ludowej }\end{array}$ & $\begin{array}{c}\text { Organizacja } \\
\text { wycieczek } \\
\text { po okolicy, } \\
\text { pikników }\end{array}$ & $\begin{array}{c}\text { Program } \\
\text { edukacyjny } \\
\text { dla dzieci }\end{array}$ & $\begin{array}{c}\text { Oferta dla grup } \\
\text { dzieci (zielone } \\
\text { szkoły) }\end{array}$ \\
\hline $\begin{array}{c}\text { Liczba go- } \\
\text { spodarstw }\end{array}$ & 3 & 6 & 8 & 3 & 3 \\
\hline
\end{tabular}

* MODR - Mazowiecki Ośrodek Doradztwa Rolniczego 
Agroturystyka jest formą działalności, która wymaga, aby gospodarz miał specjalne predyspozycje osobowości, umiejętności interpersonalne i otwarte ekstrawersyjne usposobienie. Cechy te ułatwiają dwustronne relacje i wpływają na zadowolenie turystów i ich decyzje do ponownego odwiedzenia gospodarstwa. Respondenci pytani, na czym polega dobre przygotowanie do prowadzenia wiejskiego hoteliku i kierowanie gospodarstwem przyjmującym gości, podawali różne odpowiedzi: uprzejmość (31\%), łatwe nawiązywanie kontaktów (26\%), cierpliwość do gości i ich wymagań (18\%), zapewnienie dobrych posiłków (12\%). Znamienną cechą jest to, ze żadna $\mathrm{z}$ ankietowanych osób nie wskazała na potrzebę przygotowania do pełnienia funkcji przewodnika po regionie. Dominuje, zatem myślenie o zapewnieniu warunków socjalno-bytowych i stworzeniu gościom miłej atmosfery pobytu.

$Z$ badań wynika, że w prawie wszystkich gospodarstwach, przynajmniej jeden z domowników zna w stopniu co najmniej średnio zaawansowanym język obcy, co ułatwia przyjmowanie turystów z zagranicy i umożliwia także rozszerzenie działań edukacyjnych na osoby przybywające na odpoczynek z innych krajów.

Sondaż wykazal, że oferta atrakcji związanych z edukacją oferowanych przez gospodarzy w bezpośredniej rozmowie jest bogatsza, niż ta przedstawiona w opracowaniu MODR. Gospodarze zgłosili szereg propozycji, które zestawiono w tabeli 2.

Tab. 2. Oferta gospodarstw agroturystycznych majaca zwiqzek z edukacjo (na podstawie sondażu bezpośredniego)

\begin{tabular}{|c|c|c|c|c|c|c|c|c|c|c|c|c|c|c|}
\hline \multirow{2}{*}{ 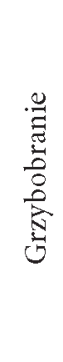 } & \multirow{2}{*}{ 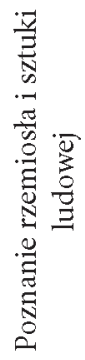 } & \multirow{2}{*}{ 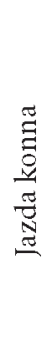 } & \multicolumn{3}{|c|}{$\begin{array}{c}\text { Sprzęt } \\
\text { rekreacyjny }\end{array}$} & \multirow{2}{*}{ 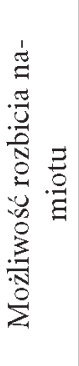 } & \multirow{2}{*}{ 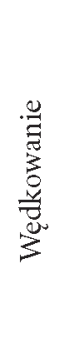 } & \multirow{2}{*}{ 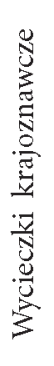 } & \multirow{2}{*}{ 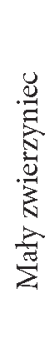 } & \multirow{2}{*}{ 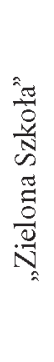 } & \multirow{2}{*}{ 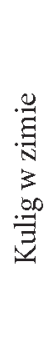 } & \multirow{2}{*}{ 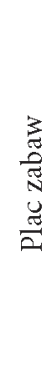 } & \multirow{2}{*}{ 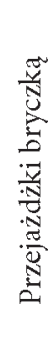 } & \multirow{2}{*}{ 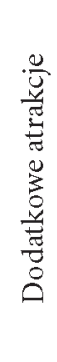 } \\
\hline & & & 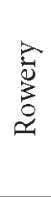 & 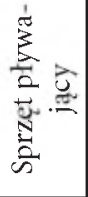 & $\begin{array}{l}\frac{\pi}{\tilde{m}} \\
\frac{\pi}{0} \\
\infty\end{array}$ & & & & & & & & & \\
\hline 19 & 7 & 13 & 18 & 11 & 7 & 6 & 19 & 18 & 3 & 17 & 6 & 10 & 8 & $13^{*}$ \\
\hline
\end{tabular}

W gospodarstwach położonych w pobliżu rzek i jezior główną atrakcją jest wędkowanie z możliwością poznania różnych gatunków ryb, ich morfologii, zróżnicowania gatunkowego i anatomii (przy własnoręcznie wykonywanym pa- 
troszeniu - także jedna z letnich atrakcji dla osób związanych z miastem, stołujących się w restauracjach). W niektórych gospodarstwach istnieje możliwość korzystania ze sprzętu pływającego (kajak, łódka, ponton), a gospodarze oferują również naukę pływania, sporty wodne oraz krajoznawcze rejsy łodzią.

Gospodarstwa położone w pobliżu lasów oferują możliwość korzystania $\mathrm{z}$ wszelkich jego uroków. Jedną z propozycji jest grzybobranie stwarzające możliwość pogłębiania wiedzy o lesie i różnorodności występujących tam organizmów. Po powrocie na kwaterę, od gospodarzy można nauczyć się oryginalnych sposobów robienia przetworów według tradycyjnych, regionalnych receptur, na co właśnie nie tylko w naszym kraju wraca moda.

W większości gospodarstw, coraz bardziej powszechne staje się wykorzystywanie koni jako atrakcji agroturystycznej. Hippika, a także hipoterapia to nie tylko sprzyjający zdrowiu wypoczynek czy leczenie, ale także okazja do poznania biologii tego gatunku zwierzęcia oraz w praktyce przećwiczenia zasad żywienia i wykonywania zabiegów pielęgnacyjnych. Niestety w objętych badaniami gospodarstwach, poza paroma gatunkami zwierząt hodowlanych, nie są zorganizowane małe ogrody zoologiczne. O tym kierunku rozwoju nie należy zapominać, gdyż jest to szczególna atrakcja dla małych dzieci, a codzienna obserwacja zwierząt umożliwia poznanie ich biologicznego rytmu życia i behawioru.

Właściciele niektórych gospodarstw umożliwiają poznanie zanikającego rzemiosła oraz sztuki ludowej (warsztaty tkackie, rękodzieło artystyczne, warsztaty lalkarskie, malarskie, oraz wiele innych dodatkowych atrakcji). Prawie we wszystkich odwiedzonych agroturystycznych kwaterach są organizowane wycieczki krajoznawcze po okolicy (83\%). Rola gospodarzy ogranicza się jednak tylko do zorganizowania przejazdu turystom. Brak jest natomiast zapewnienia profesjonalnej obsługi przewodnickiej, aby mogli oni poznać historię, kulturę $\mathrm{i}$ tradycję ludzi zamieszkujących te tereny.

Niektórzy gospodarze wzbogacają ofertę o dodatkowe atrakcje dla dzieci: plac zabaw czy boiska do gry w piłkę nożną, siatkową, koszykową. W pojedynczych gospodarstwach można także grać w tenisa.

Objęte badaniami gospodarstwa mają ograniczone liczbowe możliwości kwaterowania, dlatego nie są nastawione na przyjmowanie dużych grup. Gospodarze myślą jednak o nawiązywaniu współpracy i przygotowywaniu programów dla młodzieży w ramach „zielonych szkół”. Wzrasta bowiem zapotrzebowanie na tego typu usługi ze strony szkół pracujących w dużych aglomeracjach miejskich, gdzie kontakt z naturalnym środowiskiem jest bardzo utrudniony. Lekcje przyrody poza miastem są dla nich niekiedy jedyną szansą bliskiego poznania świata zwierząt czy roślin i sprzyjają integracji nauczania treści przyrodniczych z programami międzyprzedmiotowych ścieżek edukacyjnych: ekologicznej, regionalnej i prozdrowotnej. 
Każda miejscowość charakteryzuje się swoistymi cechami krajobrazu. W ocenie 38\% respondentów do najważniejszych elementów wpływających na niepowtarzalny charakter przyrodniczej przestrzeni w ich miejscowości należy las. Spełnia on w środowisku zarówno funkcje przyrodnicze, jak i gospodarcze, a jego wyjątkowa rola w rekreacji staje się swoistą atrakcją turystyczną. Drugim, co do ważności wymienianym elementem krajobrazu, są zbiorniki wodne - jeziora, stawy, rzeki (33\%).

Ankietowani zwracają także uwagę na znaczenie dla turystów takich obiektów przyrodniczych jak łąka, czy różne uprawy roślinne. Udział w sianokosach jest, zdaniem części uczestników sondażu, dla niektórych turystów wielką przygodą.

Większość gospodarstw położonych jest w pobliżu obszarów chronionych (74\%), co niewątpliwie stanowi czynnik przyciągający turystów. Rezerwaty, obszary chronionego krajobrazu i parki krajobrazowe znajdujące się w pobliżu gospodarstw są ważnym atutem i magnesem dla turystów spragnionych kontaktu z czystym środowiskiem przyrodniczym.

Coraz więcej gospodarstw agroturystycznych powstaje w pobliżu lub na terenach prawnie chronionych, czego przykładem są te, opisywane w tej pracy. Osoby obsługujące ruch turystyczny na takich obszarach mogą wykonać dużą pracę edukacyjną, pod warunkiem, że same będą do tego dobrze przygotowane. Gospodarze wiejskich kwater powinni być zainteresowani szkoleniem turystów, ponieważ od stanu przyrody w ich otoczeniu zależy trwałość funkcji turystycznej gospodarstw, które prowadzą. W tym kontekście trzeba zauważyć, że wartość krajobrazu z punktu widzenia turysty, najlepiej jest wyrażać w kategoriach aksjologicznych, ekologicznych i estetycznych, a z punktu widzenia gospodarzy dodatkowo w kategorii ekonomicznej.

Pełnienie funkcji edukacyjnej w gospodarstwie agroturystycznym wymaga przede wszystkim prowadzenia podręcznej biblioteczki wyposażonej w przewodniki po okolicy, atlasy roślin i zwierząt. Do obserwacji przyrodniczych warto mieć do dyspozycji gości lornetki, lupy, rowery. Warto dysponować kalendarzem imprez planowanych w regionie i rozkładem jazdy komunikacji publicznej. Nie znające terenu osoby przyjezdne, chętnie skorzystają z usług miejscowego przewodnika, który pokaże to, co warto obejrzeć w danej okolicy. Rolnik rozpoczynający obsługę ruchu turystycznego powinien rozpocząć od dobrego poznania swojego regionu. Wiedza ta jest potrzebna, aby umiał odpowiadać na pytania ze strony gości dotyczące zabytków i otaczającej przyrody, potrafił wskazać miejsca warte odwiedzenia, zaproponował w sposób wariantowy trasy zwiedzania, a jeśli zajdzie taka potrzeba, podjął się roli przewodnika podczas zwiedzania. Wydaje się, że ten rodzaj umiejętności gospodarzy może stać się ważnym czynnikiem zachęcającym do przyjazdu na wczasy, dla osób chcących oprócz wypoczynku poświęcić wolny czas na poznanie czegoś nowego. Jak wynika z odpowiedzi udzielonych na pytania ankiety, znaczna część właścicieli gospodarstw agroturystycz- 
nych ocenia swoje przygotowanie do pełnienia roli przewodnika przyrodniczego jako dobre (37\%). O tym, że nie są przygotowani do takiego zadania lub nigdy o tym nie myśleli informuje $22 \%$ zapytanych o to gospodarzy. Zadowalająco należy ocenić fakt, że $86 \%$ respondentów stwierdza, że zna podstawowe gatunki roślin i zwierząt w swojej okolicy i może wykorzystać tą wiedzę w czasie kontaktu $\mathrm{z}$ turystami. Ponad połowa gospodarzy trudniących się agroturystyką ocenia swoje kompetencje w zakresie znajomości przyrody na tyle wysoko, że są gotowi prowadzić zajęcia dla zorganizowanych grup młodzieży realizującej program zielonych szkół (52\%). Nie sprawdzono w czasie tych badań, czy ta wysoka ocena własnych umiejętności ma pokrycie w praktyce.

Właściciele gospodarstw dostrzegają wpływ ich działalności na poprawę stanu środowiska naturalnego (64\%). Mają świadomość tego, że ich turystyczna działalność ma szansę rozwoju przede wszystkim w oparciu o produkcję ekologiczną i troskę o otaczające środowisko przyrodnicze. Ankietowani zdają sobie sprawę z tego, że na zdegradowanym terenie nie będą w stanie uzyskiwać dodatkowych dochodów, dlatego deklarują prośrodowiskową aktywność i dbałość o przyrodę w ich otoczeniu. Ten sposób myślenia, pozwala stwierdzić, że troska o środowisko wyplywa z motywacji ekonomicznej, a nie ideowej.

\section{Podsumowanie}

Gospodarstwa agroturystyczne mogą spełniać istotną rolę jako jedno z ważnych ogniw nieformalnej edukacji prośrodowiskowej społeczeństwa. Potrzebne jest do tego przygotowanie gospodarzy do prowadzenia działalności edukacyjnej. Powinni oni mieć wiedzę przyrodniczą i historyczną o lokalnym środowisku, a także posiadać podstawowe umiejętności pedagogiczne.

$\mathrm{Na}$ dzień dzisiejszy oferta gospodarstw agroturystycznych regionu siedleckiego związana jest głównie z zapewnieniem bazy pobytowej oraz udostępnieniem terenu, inwentarza i sprzętów, mniej zaś z propozycjami edukacyjnymi. Prowadzona obecnie edukacja prośrodowiskowa nie ma wyraźnie określonych celów, a więc można powiedzieć, że jest w dużym stopniu przypadkowa. Właściciele gospodarstw regionu siedleckiego jeszcze nie w pełni korzystają z potencjału swoich gospodarstw w zakresie edukacji przyjeżdżających do nich turystów. Nie w pełni też zdają sobie jeszcze sprawę z potrzeby aktywnego włączenia się $\mathrm{w}$ tego typu pracę, umieszczając edukację na końcu spraw, które wiążą się z przyjęciem gości. Tymczasem z takiej oferty chętnie korzystają przede wszystkim rodziny z dziećmi, dla których wypoczynek to coś więcej niż nocleg na wsi.

Odwiedzone w czasie prowadzenia badań gospodarstwa znajdują się w pięknym zakątku naszego kraju na terenach czystych ekologicznie. Z punktu widzenia rozwoju turystyki, walorami tego regionu są lasy pełne leśnego runa w posta- 
ci grzybów, jagód, poziomek i malin. Jego wartość podnosi znaczenie rzeka Bug, jedna z piękniejszych, nizinnych rzek, która zachowała swój naturalny, pierwotny charakter. Rozległą dolinę tej rzeki obejmują „Nadbużański Park Krajobrazowy” i „Podlaski Przełom Bugu”, dwa obszary objęte ochroną prawną, na których realizowana jest w praktyce idea zrównoważonego rozwoju. Na tym terenie zachowało się dużo ciekawych pamiątek historycznych: mogil, pomników powstańczych, zamków, pałaców, dworów i zabytków sakralnych. Rozwijają się tutaj różne dziedziny twórczości ludowej: rzeźbiarstwo, wikliniarstwo, tkactwo, hafciarstwo, malowanie na szkle, których można nauczyć się pod okiem fachowca. Właściciele gospodarstw agroturystycznych powinni wykorzystać to jako atrakcje wzbogacające i urozmaicające pobyt gościom. Turyści w szerszym niż to jest obecnie zakresie mogliby obserwować proces produkcyjny w gospodarstwie, np. siewy, zabiegi pielęgnacyjne, czy zbiory, a także obserwować i podziwiać przyrodnicze zjawiska. Dla niektórych osób przyjeżdżających na wieś, udział w codziennych pracach gospodarzy, np. dojenie krów, karmienie zwierząt, wypędzanie zwierząt na pastwisko, a w okresie letnim udział w sianokosach i zniwach, to wymarzone zajęcia znane jedynie z literatury, filmów czy opowiadań.

Rolnicy prowadzący działalność agroturystyczną wzbogacają ofertę dla turystów organizując przejażdżki bryczką, łódką, wędrówki piesze czy wyjazdy do pobliskich ciekawych miejsc (skanseny, pałace, zamki, kościoły, kapliczki, pomniki przyrody, rezerwaty, punkty widokowe). Na życzenie gości przygotowują ogniska, biesiady, kuligi, spotkania z ciekawymi ludźmi. Tym formom związanym z wypoczynkiem powinny towarzyszyć działania edukacyjne, mające jasno określony cel.

W niektórych gospodarstwach istnieją specjalnie przygotowane dla turystów ścieżki przyrodnicze z tablicami informacyjnymi. W czasie spacerów goście mają możliwość poznawania zwierząt i roślin opisanych na poglądowych tablicach.

Do gospodarstw agroturystytcznych w przeważającej części przyjeżdżają osoby z dużych aglomeracji miejskich, których wiedza z zakresu przyrody, geografii czy historii jest teoretyczna. Wypoczywając na wsi mogą wiele się nauczyć i należy tę sytuację wykorzystać.

$\mathrm{Z}$ agroturystyką związane są także usługi lecznicze noszące nazwę agroterapii. Zalicza się do nich hipoterapię, aromaterapię, apiterapię oraz specyficzną dietę o właściwościach leczniczych. Są to bardzo istotne propozycje wzbogacające turystów w wiedzę służącą utrzymaniu dobrej kondycji zdrowotnej, a ponadto ukazują one na nowo wartość środowiska przyrodniczego w aspekcie zdrowia człowieka.

Podsumowując wyniki przeprowadzonych badań sondażowych i analizując piśmiennictwo tematycznie związane $\mathrm{z}$ agroturystyką, można zaproponować następujące wnioski:

1. Agroturystyka jako jedna z form pozarolniczej aktywności gospodarczej 
mieszkańców wsi, stwarza nowe możliwości użytkowania przestrzeni wiejskiej, zabudowań rolniczych, lokalnej infrastruktury oraz nawiązuje do polskiej tradycji, od której odbiegli bardzo mieszkańcy miast. Należy poprzez odpowiednio zorganizowaną promocję upowszechniać tę formę odpoczynku związanego ze zblizeniem ludzi do ich korzeni i natury, upatrując w tym jednocześnie szansę na zmianę niekorzystnej dziś relacji człowiek - przyroda.

2. Agroturystyka gwarantuje stały kontakt $z$ naturą, jest doskonałą formą wypoczynku psychicznego i fizycznego. Dostarcza wielu przeżyć i wzruszeń w bezpośrednim obcowaniu z przyrodą, staje się czynnikiem właściwego kształtowania poglądów na potrzebę jej ochrony. Ta forma odpoczynku jest bardzo dobrą szansą pogłębienia i poszerzenia wiedzy przyrodniczej, historycznej, regionalnej, a więc można ją traktować jako ważne ogniwo w nieformalnej edukacji społeczeństwa.

3. Agrourystyka przyczynia się do podniesienia świadomości ekologicznej poprzez ukazywanie i przybliżanie wzajemnych zależności i powiązań w przyrodzie, której integralną część stanowi człowiek. Przygotowuje ona ludzi, poprzez bezpośrednie poznawanie przyrody, do proekologicznej aktywności i budzi motywację do angażowania się w ochronę przyrody.

4. Wieś ma ogromny wpływ na kulturę ogólnonarodową. Wyrazem tego są sielskie opisy w dziełach sławnych poetów, pisarzy i muzyków, dzięki czemu kultura przodków pozostaje wciąż żywa. W tym kontekście należy zaznaczyć, że ważne jest to, aby gospodarze przyjmujący turystów znali przeszłość swojej miejscowości, aby przekazywali tę wiedzę odwiedzającym ich gościom, tym samym przedstawiając jej wielkie kulturowe bogactwo.

5. Cenną wartością kulturową wsi są zachowane stroje ludowe, pamiątki przeszłości zgromadzone w izbach pamięci czy mini muzeach oraz rękodzielnictwo oparte na naturalnych surowcach. Tę wartość trzeba promować poprzez agroturystykę, przyczyniając się w ten sposób do podnoszenia ogólnego poziomu kultury społeczeństwa.

6. Wydaje się, że właściciele gospodarstw agroturystycznych mają duże możliwości oddziaływania na turystów i kształtowania kultury obcowania z przyrodą. W większym niż dotychczas stopniu powinni pełnić oni rolę przewodników - nauczycieli i wychowawców, którzy znając wartość przyrodniczego środowiska i będąc przekonanymi o potrzebie jego ochrony, edukują w tym zakresie osoby przyjezdne.

7. W terenie objętym badaniami wartością przyrody są lasy i rzeki, dlatego istnieją tu potencjalne warunki do upowszechniania edukacji leśnej i hydrobiologicznej. W tym czystym i w małym stopniu przekształconym środowisku można i trzeba wskazywać na wartość naturalnej przyrody jako materialnej podstawy egzystencji człowieka. Leży to w interesie całego społeczeństwa, 
a w szczególności osób czerpiących materialne korzyści z faktu istnienia bogatego, różnorodnego i czystego środowiska.

8. Aby szerzej rozwijać funkcję edukacyjną agroturystyki, trzeba przygotować gospodarzy kwater, poprzez organizowanie bezpłatnych szkoleń, mających na celu podniesienie ich wiedzy o własnym otoczeniu oraz wykształcenie umiejętności pedagogicznych i marketingowych. Mając odpowiedni zasób wiedzy i umiejętności jej przekazywania, gospodarze agroturystycznych kwater mogą odegrać ważną rolę w nieformalnej edukacji ekologicznej społeczeństwa.

9. Ważne jest to, aby gospodarstwa agroturystyczne były przygotowane do obsługi turystów zagranicznych. Osoby decydujące się na rozpoczęcie tej działalności powinny zainwestować we własny rozwój i przygotować się pod względem językowym do przyjęcia gości z zagranicy. Znając języki obce, gospodarze mogliby także prowadzić edukację przyrodniczą i kulturową obcokrajowców, promując jednocześnie wartości swojego regionu i kraju.

\title{
The educational function of agrotourism using the example of Siedlce region
}

\author{
SUMMARY
}

The aim of this research was to evaluate the educational offers of agrotourist farms in the Siedlce region. The research was conducted on the grounds of interviews with the farm owners and information provided by Mazowiecki Ośrodek Doradztwa Rolnieczego "Mazowsze - agrotourism 2005/2006".

The results confirm the assumption that agrotourist farms carry on an informal environmental education for their customers, but there are possibilities for improvement of this educational activity. The farm owners need appropriate preparation to fulfill the role of guides and teachers. 